\title{
The taxonomic web of the Grey Spider Flower: Grevillea buxifolia (Proteaceae)
}

\author{
J.M. Hart and M.J. Henwood
}

\begin{abstract}
Hart, J.M. and Hentwood, M.J. (John Ray Herbarium, School of Biological Sciences, Macleay Building A12, The University of Sydney, NSW 2006). The taxonomic web of the Grey Spider Flower: Grevillea buxifolia (Protenceae). Telopea 7(1): 65-76. The Grevillea buxifolia (Sm.) R. Br. species complex displays a wide range of morphological variation. The complex has undergone several taxonomic revisions in recent years, none of which has adequately accommodated the morphological variation within a robust classification. Principal component analysis and cluster analysis of 100 individuals and 35 characters were used to analyse the complex. These analyses indicated that the complex comprises four taxa. Two of the taxa are recognised as species; G. phylicoides R. Br. and G. sphacelata R. Br., and two are recognised as subspecies; G. buxifolia (Sm.) R. Br. subsp. buxifolia and G. buxifolia subsp. ecorniculata Olde \& Marriott. G. phylicoides R. Br. sensu stricto is reinstated to specific rank and G. buxifolia subsp. buxifolia is redefined to accommodate G. buxifolia subsp. phylicoides pro parte and previously intermediate individuals. All of McGillivray's races are accommodated by this scheme.
\end{abstract}

\section{Introduction}

Species serve as the basis for describing and cataloguing diversity and are considered to be the basic entities of evolutionary theory (Cracraft 1989). Many species concepts have been put forward (Stuessy 1990), but they are generally of two types; those that emphasize processes (e.g. the 'biological species concept'), and those that are pattern based and emphasize the operational means by which species are recognized (Smith 1994).

The 'biological species concept' defines a species as 'an interbreeding community of populations that is reproductively isolated from other such communities' (Mayr 1992). It has been found by many biologists to be untenable in theory, and unworkable in practice, since it can normally only be applied subjectively. Rarely do plant taxonomists have sufficient data concerning reproductive behaviour of taxa for the concept's successful application. The ability to interbreed can transcend well-defined species and even generic boundaries, and thus cannot alone establish discrete, evolutionary boundaries (Cracraft 1989; Templeton 1989). The biological species concept has only been considered to be objective in cases of sympatry and reproductive isolation, yet in such cases, other species concepts would treat the situation in the same manner (Cracraft 1989).

In practice, species recognition is often based on patterns of morphological similarity, either intuitively or based upon some combination of multivariate statistical analyses (Crisp and Weston 1993; Smith 1994). Below the level of species, the definition of taxa is even more nebulous. Five infraspecific ranks are recognised by the Code of Botanical Nomenclature (Greuter et al. 1994). There is, however, little uniformity in the use and definition of infraspecific ranks by taxonomists (Stace 1989; Hamilton and Reichard 1992). The rank of subspecies is frequently applied to populations showing any degree of differentiation considered worthy of recognition by the worker (Cracraft 1989). However, there is a need for infraspecific variation to be expressed in taxonomic terms, 
in order to draw attention to taxa and provide them with names, for communication and access to literature (Stace 1989).

Within Grevillea, there are a number of polymorphic species, some of which have been formally divided into subspecies or varieties, others informally into 'races' (McGillivray 1993). Grevillea buxifolia (Sm.) R. Br. s.lat. (Grey Spider Flower) is one such polymorphic 'species' that has received much recent attention. Grevillea buxifolia occurs in eastern New South Wales, in a coastal region centred on Sydney (Fig. 1), from Wollombi (c. $20 \mathrm{~km}$ south-west of Cessnock) in the north to Milton in the south, and west to Katoomba, in dry sclerophyll woodland, usually on sandy soils derived from Hawkesbury Sandstone (McGillivray 1993).

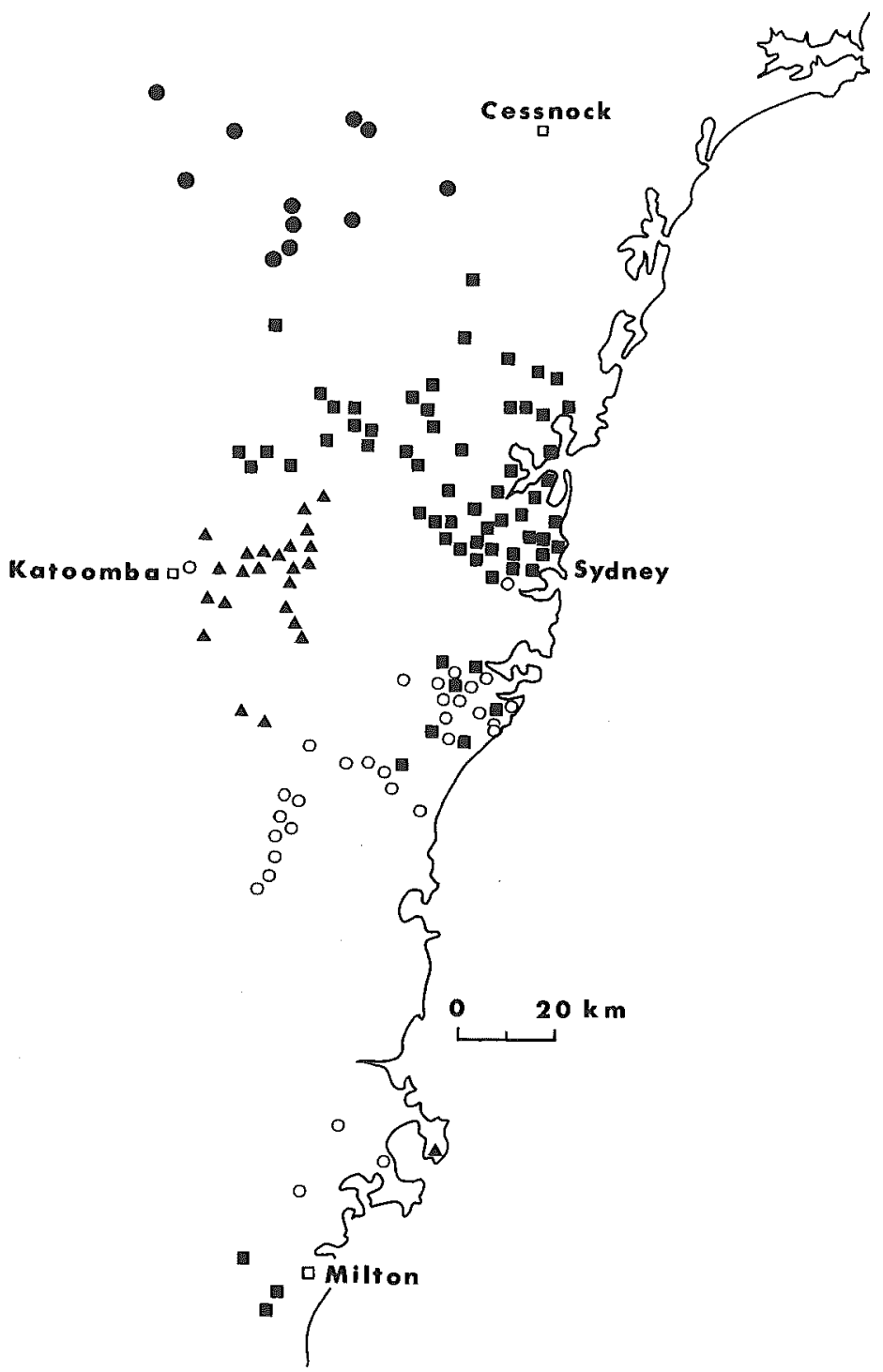

Fig. 1. Location within eastern New South Wales of populations of Grevillea buxifolia s.lat. and its segregates sampled for these analyses. G. buxifolin subsp. buxifolia, G. buxifolia subsp. ecorniculata, $\mathbf{A}$. phylicoides, O G. sphacelata. 
The G. buxifolia complex has been traditionally regarded as consisting of three closely related species: G. buxifolia, restricted to Sydney and northwards, Grevillea phylicoides R. Br. in the Blue Mountains, and Grevillea sphacelata R. Br. on the Woronora Plateau. In McGillivray's revision of the genus $(1986,1993)$ the three species were treated as one, each being reduced to subspecies of G. buxifolia. In 1986 McGillivray formally described and named Grevillea acerata, a species that had previously been regarded as a northern 'form' of G. sphacelata R. Br., and which is restricted to the Gibraltar Range, New South Wales. McGillivray (1993) also informally recognised five 'races' within G. buxifolia, two within subsp. buxifolia $\left({ }^{\prime} \mathrm{a}\right.$ ' and ' $\mathrm{c}$ '), two within subsp. phylicoides (' $\mathrm{b}$ ' and ' $d$ '), and subsp. sphacelata ('e'). McGillivray (1993), further identified three groups of populations which did not fit into his classification, since they shared features of more than one of the 'races'. Intermediates occur between races ' $b$ ' and ' $c$ ', ' $b$ ' and ' $d$ ', and ' $c$ ' and ' $d$ ' (McGillivray 1993). However, the morphologically extreme races, ' $c$ ' and ' $\mathrm{e}$ ', occur sympatrically at a number of locations, without apparent signs of interbreeding (McGillivray 1993; Olde and Marriott 1994a; pers. obs.). Such populations are known to occur in the $\mathrm{O}^{\prime}$ Hares Creek Catchment, around Woronora Dam, Lucas Heights, Royal National Park, Illawong and, possibly, Gladesville.

Olde and Marriott (1993a, b; 1994a, b, c; 1995) have revised a number of taxa that had been previously regarded by McGillivray as subspecies or forms. Olde and Marriott (1994a), drawing partly on McGillivray's work, formally described and named McGillivray's race 'a' as G. buxifolia subsp. ecorniculata Olde \& Marriott, and reinstated subspecies sphacelata to species rank. Olde and Marriott (1994a) did not, however, address the taxonomic status of the intermediate entities within the complex.

Thus, as the taxonomy currently stands, G. buxifolia comprises three subspecies: buxifolia, ecorniculata and phylicoides - each with one or two forms - and with some intermediates. Grevillea buxifolia appears to be most closely allied to both G. sphacelata and G. acerata. McGillivray's concept of a species is morphological, whereas Olde and Marriott (1993b) have defined their own biologically-based species concept. Thus the G. buxifolia complex serves as an ideal model with which to investigate the ideas and techniques involved in the delimitation and ranking of species and infraspecific taxa.

The current study attempts to clarify the taxonomic position of the intermediate individuals present in the G. buxifolia complex by way of principal components analysis and cluster analysis, and in doing so reassesses the status of the currently recognised taxa.

\section{Methods}

A total of 100 flowering specimens (OTUs) of G. buxifolia s.lat. were chosen to represent the geographic range and morphological variation exhibited by the complex. Of the $100 \mathrm{G}$. buxifolia individuals used in the analyses, 12 were from G. buxifolia subsp. ecorniculata (race ' $a$ '), 8 were from G. buxifolia subsp. phylicoides pro parte (race ' $b$ '), 22 G. buxifolia subsp. buxifolia (race ' $c$ '), 17 G. buxifolia subsp. phylicoides sensu stricto (race 'd'), 28 G. sphacelata (race ' $\mathrm{e}^{\prime}$ ), and 13 could not be assigned to a race. An additional three specimens of $G$. acerata were included in the analysis, because of this taxon's previous inclusion within G. sphacelata.

Specimens were collected in the field (vouchers lodged at SYD), or were sampled from herbarium specimens from the John Ray Herbarium (SYD) and National Herbarium of NSW (NSW). Prior to measurement the fresh leaves and flowers were stored in a 5\% glycerine in $65 \%$ alcohol mixture, whereas material sampled from herbarium. specimens was rehydrated prior to measurement by heating in a weak detergent solution. Where possible, character reliability of both spirit preserved and rehydrated organs was checked by reference to fresh material. 
Where appropriate, the characters employed by McGillivray (1993) and Olde and Marriott (1994a) were included in the data set. In total, twenty-four floral and eleven foliar characters were measured (Appendix 1). Each character was measured from three flowers or from three leaves per specimen; the means were subsequently used to represent each specimen in the analysis. The leaves were removed from the fifth, sixth and seventh nodes below an open conflorescence to reduce allometric differences between individuals.

Computerised image analysis was utilised in the measurement of six of the leaf characters. Unscaled leaves were digitised using a Tracor Northern TN-8502 computer (IPA85 imaging software, Tracor Northern 1987) fitted with a Sony DXC-3000P CCD colour video camera. Measurements of floral characters were made directly using an eye-piece graticule on a dissecting microscope.

Numerical analyses were performed using 'A MultiVariate Statistical Package' (MVSP Ver. 2.1, Kovach 1993) computer program, run on an IBM-compatible PC. The data were range-coded to prevent those characters with the greatest range from dominating the analysis (Sneath and Sokal 1973). Principal components analysis was undertaken using Euclidean distance. The cluster analysis employed Gower's similarity metric (Gower 1971), and was combined with a UPGMA (unweighted pair-group method using averages) clustering strategy (Sneath and Sokal 1973).

The chromosome numbers of all races of G. buxifolia s.lat. were determined from studies of meiosis, obtained from pollen mother cells fixed in 1:3 acetic-alcohol and stained in aceto-carmine.

\section{Results}

The observed chromosome numbers indicated that all races of G. buxifolia s.lat. are diploid. The chromosome number of all races was $n=10$ (Table 1 ).

Ordination of the first three principal components (Fig. 2) resulted in the resolution of five main groups: G. acerata, G. sphacelata, G. buxifolia subsp. phylicoides sensu stricto (race 'd'), G. buxifolia subsp. ecorniculata (race 'a') and a group comprising G. buxifolia subsp. buxifolia, G. buxifolia subsp. phylicoides pro parte (race ' $b$ ') and all of the unassigned OTUs. The first three principal components accounted for $68.2 \%$ of the total variance (Table 2 ).

Grevillea acerata and G. sphacelata are separable from the other OTUs in the first principal component (Fig. 2a) based on the extent of stem and petiole trichome appression (characters 25 \& 26). The second principal component separates G. buxifolia subsp. phylicoides sensu stricto (race ' $\mathrm{d}$ ') from the other OTUs (Fig. 2a \& c) on the basis of the erect trichomes on its abaxial leaf surfaces (character 35). Grevillea buxifolia subsp. ecorniculata formed an identifiable subgroup of the G. buxifolia complex (races ' $c$ ', ' $b$ ' and unassigned OTUs) in the third principal component (Fig. 2b) because of its lack of a stylar appendage (character 23).

Cluster analysis (Fig. 3) resulted in the resolution of the same five groups as determined by Principal Components Analysis (PCA). The only conflict between the PCA and cluster analysis involved the apparent affinities of the unassigned OTUs. In contrast with the PCA, four of the 13 unassigned. OTUs were placed with G. buxifolia subsp. phylicoides sensu stricto (race ' $\mathrm{d}$ '). All race ' $\mathrm{b}$ ' OTUs and the nine remaining unassigned OTUs were nested within the race ' $c$ ' OTUs in the cluster analysis, however, it is clear from the ordination that all of the unassigned OTUs are unequivocally associated with a group dominated by G. buxifolia subsp. buxifolia (races ' $b$ ' and ' $c$ '). 

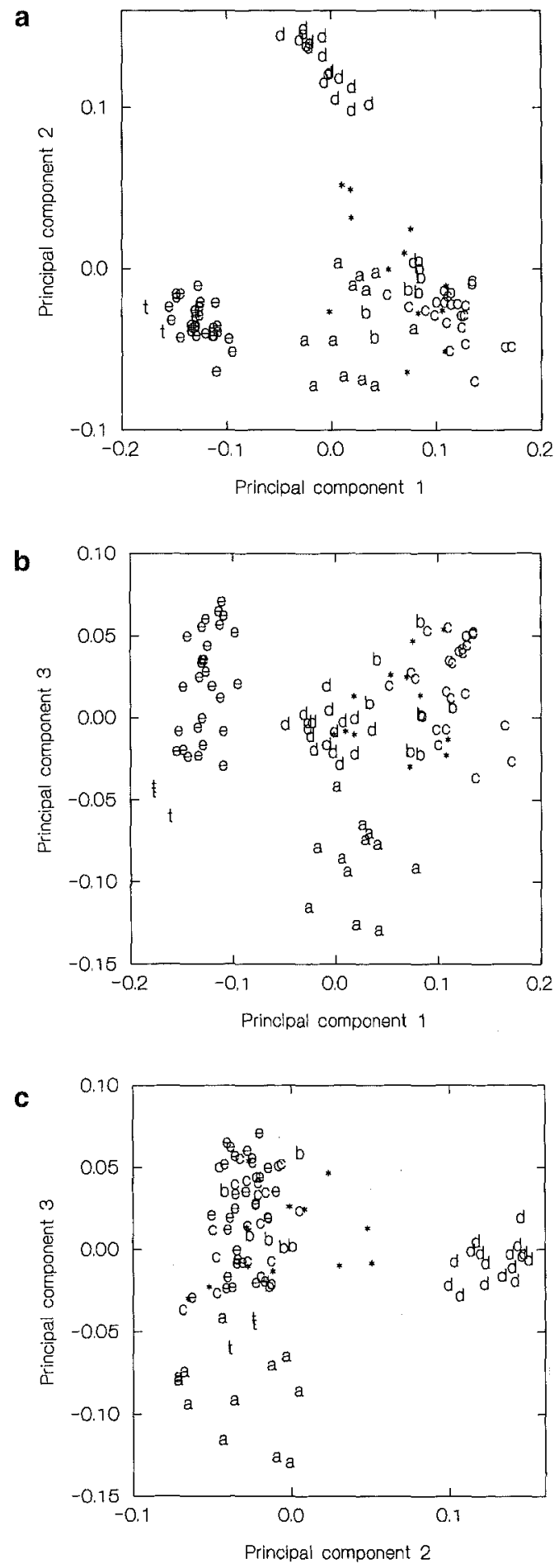

Fig. 2. Ordination of the first three principal components. a, principal components 1 and 2; b, principal components 1 and 3; c, principal components 2 and 3. (a - G. buxifolia subsp. ecorniculata, $\mathrm{b}-\mathrm{G}$. buxifolia subsp. phylicoides pro parte race ' $\mathrm{b}$ ', $\mathrm{c}-\mathrm{G}$. buxifolia subsp. buxifolia, $\mathrm{d}-\mathrm{G}$. buxifolia subsp. phylicoides sensu stricto race ' $\mathrm{d}$ ', $\mathrm{e}-\mathrm{G}$. sphacelata, $\mathrm{t}-\mathrm{G}$. acerata, ${ }^{*}$ - unassigned OTUs). 


\section{Discussion}

These analyses indicated that G. buxifolia comprises two entities: (1) G. buxifolia subsp. ecorniculata and (2) G. buxifolia subsp. buxifolia, G. buxifolia subsp. phylicoides pro parte (race ' $b$ ') and all of the previously unassigned OTUs. Grevillea buxifolia and G. phylicoides sensu stricto (race ' $d$ '), as defined here, are separable from G. acerata and G. sphacelata.

A significant amount of the phenetic pattern of variation within the Grevillea buxifolia complex was found to be size-related. The flowers of G. buxifolia subsp. buxifolia (race ' $c$ ') are noticeably larger than those of the other races, suggesting the possible presence of polyploidy. However, chromosome counts determined that polyploidy is not, apparently, present within the G. buxifolia complex.

Chromosome number alone is also uninformative as to the possible reproductive isolation of any of the taxa. To prove reproductive isolation is difficult, if not impossible in a genus

Table 1. Chromosome numbers in the Grevillea buxifolia complex. Voucher specimens lodged at SYD.

\begin{tabular}{|c|c|c|}
\hline Taxon & Chromosome no. & Voucher \\
\hline race 'a' & $n=10$ & $\begin{array}{l}\text { Staircase Hill, } 7.9 \mathrm{~km} \text { S of Putty turnoff, on the Putty Road, } \\
\text { NSW. J.M.Hart } 94023 \text { 9/4/1994 }\end{array}$ \\
\hline race ' $b$ ' & $\mathrm{n}=10$ & $\begin{array}{l}\text { c.32km N of Windsor on the Putty Road, NSW. J.M.Hart } \\
940199 / 4 / 1994\end{array}$ \\
\hline race ' $c$ ' & $n=10$ & $\begin{array}{l}\text { Oxford Falls Road, 0.8km W of Oxford Falls, NSW. J.M. Hart } \\
9405021 / 8 / 1994\end{array}$ \\
\hline race ${ }^{\prime} d^{\prime}$ & $n=10$ & Bruce Road, Glenbrook, NSW. A.J.Perkins s.n. 10/4/1994 \\
\hline race 'e' & $\mathrm{n}=10$ & $\begin{array}{l}\text { Woronora Dam Road, } 5.6 \mathrm{~km} \text { from Princes Hwy, NSW. } \\
\text { J.M. Hart } 94004 \text { 26/1/1994 }\end{array}$ \\
\hline
\end{tabular}

Table 2. Character loadings of the major characters and percentages of total variation for the first three axes of the principal components analysis.

Character

6. Limb length

7. Limb length:Perianth height

8. Perianth length

14. Style length

16. Style length: width

18. Pollen-presenter width

20. Appendage length (no trichomes)

21. Appendage length (with trichomes)

22. Appendage trichome length

23. Appendage shape

25. Stem indumentum

26. Petiole indumentum

34. Leaf abaxial trichome density

35. Leaf abaxial trichome state

$\%$ variation

cumulative $\%$ variance
AXIS 1

0.204

0.093

0.215

0.200

0.068

0.153

0.219

0.237

0.212

0.169

0.403

0.385

$-0.236$

$-0.015$
AXIS 2

$-0.131$

$-0.049$

$-0.145$

$-0.129$

$-0.029$

$-0.145$

$-0.043$

$-0.051$

$-0.062$

0.014

0.253

0.387

$-0.432$

0.561
AXIS 3

$-0.134$

$-0.243$

$-0.007$

0.125

0.281

$-0.260$

0.264

0.276

0.210

0.529

$-0.245$

$-0.001$

0.054

$-0.060$

43.22

16.69

8.29

43.22

59.91

68.20


in which there exists widespread self-compatibility (McGillivray 1993), and many naturally occurring hybrids between otherwise distinct species (e.g. McLuckie 1930).

According to the biological species concept, reproductive isolation is the process which delineates species. Use of reproductive isolation to define plant species makes their identification largely conjectural since morphological disparity or similarity has no necessary place in the definition of the biological species. The mismatch between reproductive isolation and morphological distinctness is evident from the literature on cryptic, sibling and polytypic species (Cracraft 1989; Smith 1994), and the common occurrence of hybridization between morphologically and evolutionarily distinct
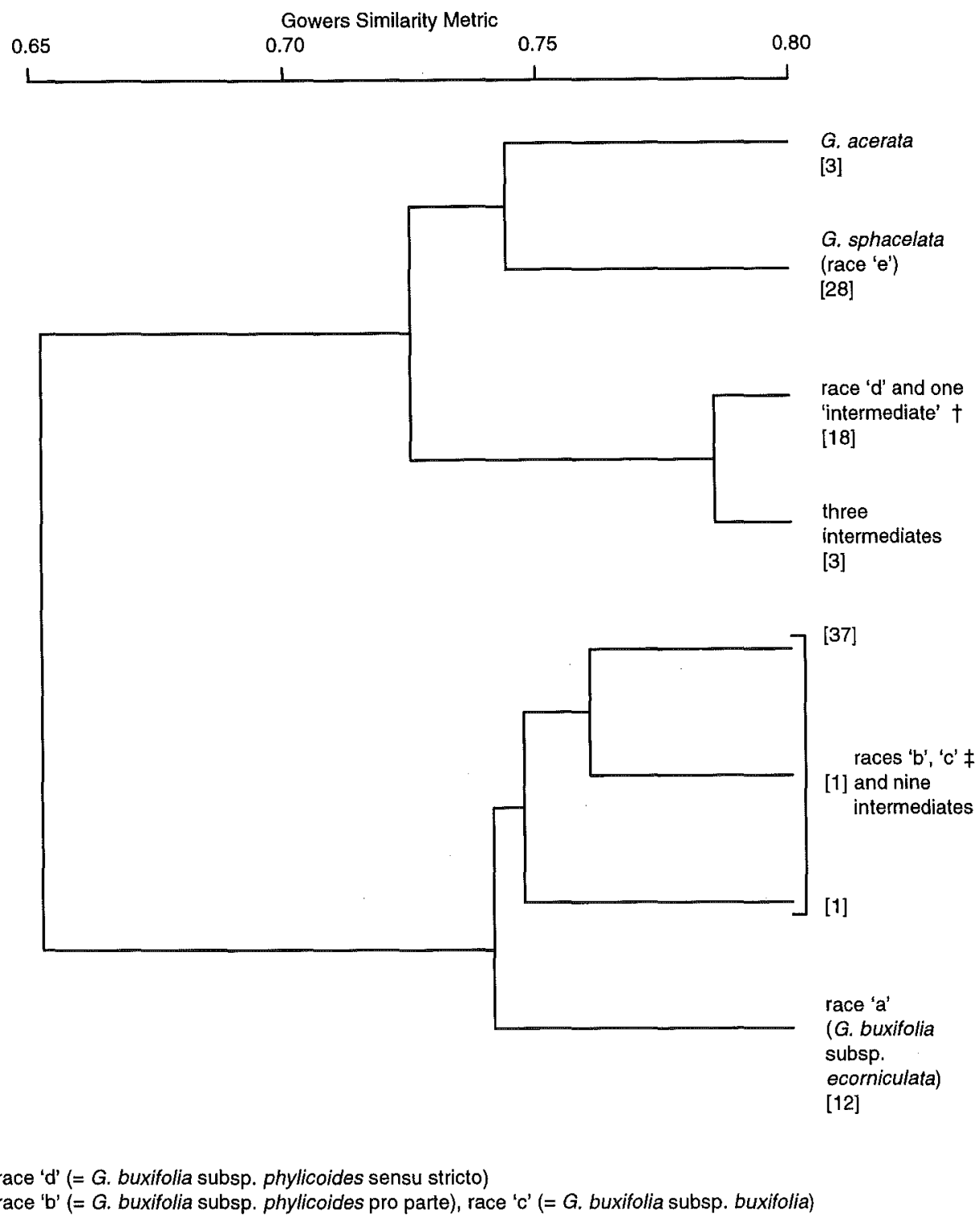

Fig. 3. Dendrogram resulting from the cluster analysis, indicating the presence of four groups within the Grevillea buxifolia complex. NB. clusters above 0.80 similarity not shown. Number of OTUs in each cluster given in square brackets. 
plant species (Stuessy 1990). Reproductive isolation is merely a subset of the numerous possible consequences of the more general process of differentiation (Cracraft 1989). Thus, in practice, the biological species complex is difficult to apply successfully.

The morphological species concepts are commonly employed. It is assumed that morphological relationships do reflect genetic and reproductive relationships. Morphological data are the most easily obtained, and phenetic methods can handle large data sets in which there are complex patterns of variation. However, defining species morphologically also has faults, and critics believe that this approach is too subjective. Users of the phenetic species concept have to decide which phenetic unit is the one to be called a species (Stuessy 1990). A specific level of dissimilarity, above which two taxa should be recognised as separate species, subspecies, or other rank, cannot be determined and applied uniformly. In addition to this, there are a number of examples in which biochemical and molecular techniques are in absolute disagreement with morphological species, or with each other (King 1993). Thus, the biological species concept and morphological species concepts each carry their own sets of implications and limitations (Smith 1994).

Here, the taxonomy of the Grevillea buxifolia species complex is based upon morphological data.

\section{Taxonomic conclusions}

It is clear from these analyses that $G$. buxifolia subsp. phylicoides is divisible into two groups: race ' $b$ ' and race ' $d$ '. Individuals conforming to race ' $b$ ' and the previously unassigned individuals are easily accommodated within G. buxifolia subsp. buxifolia whereas those conforming to race ' $\mathrm{d}$ ' merit recognition at the species level. Race ' $\mathrm{d}$ ' conforms precisely to Brown's concept of G. phylicoides as lectotypified by Makinson (1997 ined.), and, therefore, requires reinstatement to species level and a redefinition of the concept of G. buxifolia subsp. buxifolia. Grevillea buxifolia subsp. ecomiculata (race 'a') forms an identifiable, but phenetically similar, subgroup of G. buxifolia based only on a single character; the lack of the stylar appendage. Thus on the basis of these analyses, continued recognition of Grevillea buxifolia subsp. ecorniculata is recommended. Grevillea buxifolia as defined here consists of two subspecies: buxifolia and ecorniculata, and is separable at the species level from G. acerata, G. phylicoides and G. sphacelata as outlined in Table 3 and below.

Table 3: Recent taxonomic concepts in the Grevillea buxifolia complex and taxonomic recommendations. species boundaries, subspecies boundaries, ........ race boundaries.

\begin{tabular}{|c|c|c|c|c|}
\hline $\begin{array}{l}\text { Original } \\
\text { taxonomy }\end{array}$ & McGillivray, 1986 & McGillivray, 1993 & $\begin{array}{c}\text { Olde \& Marriott, } \\
1994\end{array}$ & $\begin{array}{c}\text { Taxonomic } \\
\text { Recommendations }\end{array}$ \\
\hline \multirow{2}{*}{$\begin{array}{l}\text { Grevillea } \\
\text { buxifolia }\end{array}$} & $\begin{array}{l}\text { Grevillea buxifolia } \\
\text { subsp. buxifolia }\end{array}$ & race 'a' & $\begin{array}{c}\text { Grevillea buxifolia } \\
\text { subsp. ecorniculata }\end{array}$ & $\begin{array}{l}\text { Grevillea buxifolia } \\
\text { subsp. ecorniculata }\end{array}$ \\
\hline & $\begin{array}{l}\text { Grevillea buxifolia } \\
\text { subsp. buxifolia }\end{array}$ & race ' $c$ ' & $\begin{array}{l}\text { Grevillea buxifolia } \\
\text { subsp. buxifolia }\end{array}$ & \multirow{2}{*}{$\begin{array}{l}\text { Grevillea buxifolia } \\
\text { subsp. buxifolia } \\
\text { Grevillea buxifolia } \\
\text { subsp. buxifolia }\end{array}$} \\
\hline \multirow{2}{*}{$\begin{array}{c}\text { Grevillea } \\
\text { phylicoides }\end{array}$} & $\begin{array}{l}\text { Grevillea buxifolia } \\
\text { subsp. phylicoides }\end{array}$ & race ' $b$ ' & \multirow{2}{*}{$\begin{array}{l}\text { Grevillea buxifolia } \\
\text { subsp. phylicoides } \\
\text { Grevillea buxifolia } \\
\text { subsp. phylicoides }\end{array}$} & \\
\hline & $\begin{array}{l}\text { Grevillea buxifolia } \\
\text { subsp. phylicoides }\end{array}$ & race ' $d$ ' & & Grevillea phylicoides \\
\hline $\begin{array}{c}\text { Grevillea } \\
\text { sphacelata }\end{array}$ & $\begin{array}{l}\text { Grevillea buxifolia } \\
\text { subsp. sphacelata }\end{array}$ & race 'e' & Grevillea sphacelata & Grevillea sphacelata \\
\hline
\end{tabular}




\section{Nomenclature}

Grevillea buxifolia (Sm.) R. Br., Trans. Linn. Soc. London 10: 174 (1810).

Embothrium buxifolium Sm., A Specimen of the Botany of New Holland: 29 t.10. (1794).

Stylurus buxifolia (Sm.) Knight, On the Cultivation of Plants Belonging to the Natural Order of the Proteeae: 115 (1809).

Grevillea buxifolia Sm. (R.Br) subsp. buxifolia, see McGillivray, New Names in Grevillea (Proteacene): 3 (1986).

Embothrium genianthum Cavanilles, Ic. \& Descr. Pl. 4: 60 t.387 (1798).

Grevillea buxifolia race 'b' (informal) McGillivray, Grevillea (Proteaceae): A taxonomic revision: $312-314$ (1993).

Grevillea buxifolia race 'c' (informal) McGillivray, Grevillea (Proteaceae): A taxonomic revision: $312-314$ (1993).

Geographic distribution: Central Coast: from north of Gosford, south to Port Jackson. and inland to Bucketty, Culoul Range and Bilpin, as well as south of the Georges River to Appin and Bulli Pass on the Woronora Plateau.

South Coast: Restricted to Pigeon House Mountain near Milton.

Apparently intergrading populations with Grevillea phylicoides occur in the Bilpin-Kurrajong area. Grevillea buxifolia subsp. buxifolia co-occurs with Grevillea sphacelata without intergrading at Gladesville, lllawong, Royal National Park, Lucas Heights, Woronora Dam and the O'Hares Creek Catchment.

Grevillea buxifolia subsp. ecorniculata Olde \& Marriott, Telopea 5(4): 709 (1994).

Grevillea buxifolia race 'a' (informal) McGillivray, Grevillea (Proteaceae): A taxonomic revision: 312-314 (1993).

Geographic distribution: Central Coast: In the region around the town of Putty, between Howes Mountain to Wollombi and Mount Coricudgy.

Grevillea phylicoides R. Br., Trans. Linn. Soc. London 10: 174 (1810).

Grevillea scabrifolia Gandoger, Bull. Soc. Bot. France 66: 231 (1919).

Grevillea buxifolia subsp. phylicoides (R. Br.) McGillivray, Newv Names in Grevillea (Proteaceae): 3 (1986) pro parte.

Grevillea buxifolia race 'd' (informal) McGillivray, Grevillea (Proteaceae): A taxonomic revision: 312-314 (1993).

Geographic distribution: Central Coast: Lower Blue Mountains from Glenbrook to Lawson, north to Grose Wold and south to Oakdale.

South Coast: Known from a single collection on Beecroft Peninsula.

This species apparently intergrades with Grevillea buxifolia subsp. buxifolia in the Kurrajong-Bilpin area. 
Grevillea sphacelata R. Br., Trans. Linn. Soc. London 10: 174 (1810).

Grevillea walteri Gandoger, Bull. Soc. Bot. France 66: 231 (1919).

Grevillea buxifolia subsp. sphacelata (R. Br.) McGillivray, New Names in Grevillea (Proteaceae): 3 (1986).

Grevillea buxifolia race 'e' (informal) McGillivray, Grevillea (Proteaceae): A taxonomic revision: 312-314 (1993).

Geographic distribution: Central Coast: From Gladesville in the coastal region south to Bulli and inland to Picton and Mittagong.

Central Tablelands: Known from a single collection at Leura.

South Coast: From Jervis Bay inland to Conjola.

Co-occurs with Grevillea buxifolia subsp. buxifolia without intergrading at Gladesville, Illawong, Royal National Park, Lucas Heights, Woronora Dam and the O'Hares Creek Catchment.

\section{Name of uncertain application}

Grevillea collina (Knight) Sweet, Hortus Suburbanus Londonensis: 22 (1818).

Stylurus collina Knight, On the Cultivation of Plants Belonging to the Natural Order of the Proteeae: 116 (1809).

This name may be applicable to either Grevillea sphacelata or Grevillea phylicoides, however the protologue in the absence of a specimen or illustration, is insufficient for the purposes of circumscription.

\section{Key to Grevillea buxifolia and morphologically similar species}

1 Stem covered by an appressed, subsericeous to subvillous indumentum

2 Flowers with sutures adaxially oriented

G. acerata

$2^{*}$ Flowers with sutures abaxially oriented

3 Conflorescences borne terminally and in leaf axils ........... G. occidentalis

$3^{*}$ Conflorescences borne terminally only

G. sphacelata

$1^{*}$ Stem covered by a spreading, villous to tomentose indumentum

4 Leaves covered by erect hairs below, linear-oblong to narrowly elliptic, 7-30 $\mathrm{mm}$ long, 3-5 mm wide; pollen-presenter elliptic to narrow elliptic, 1-1.6 mm wide

G. phylicoides

$4^{*}$ Leaves covered by appressed hairs below, elliptic to ovate, 5-25 mm long, 2-6.5 mm wide; pollen-presenter round to elliptic, $1.4-3.3 \mathrm{~mm}$ wide

G. buxifolia

5 Stylar appendage $>1.4 \mathrm{~mm}$ long

G. buxifolia subsp. buxifolia

$5^{*}$ Stylar appendage absent or rarely to $1.3 \mathrm{~mm}$ long

G. buxifolia subsp. ecorniculata 


\section{Acknowledgments}

The authors gratefully acknowledge Bob Makinson and Don McGillivray for their comments on an earlier draft of this paper. The National Herbarium of NSW is thanked for providing access to collections and Peter Weston is thanked for his assistance at NSW.

\section{References}

Cracraft, J. (1989) Speciation and its Ontology: The Empirical Consequences of Alternative Species Concepts for Understanding Patterns and Processes of Differentiation. Pp. 28-59 in D. Otte and J. A. Endler (Eds.) Speciation and its Consequences. (Sinauer Associates Inc: Massachusetts).

Crisp, M.D. and Weston, P.H. (1993) Geographic and Ontogenetic Variation in Morphology of Australian Waratahs (Telopea: Proteaceae). Systematic Biology 42: 49-76.

Gower, J.C. (1971) A general coefficient of similarity and some of its properties. Bionetrics 27: 857-871.

Greuter, W. (ed., chairman) (1994) 'International Code of Botanical Nomenclature' (Tokyo Code) as Adopted by the Fifteenth International Botanical Congress, Yokohama, August-September, 1993. Regnum Vegetabile 131.

Hamilton, C.W. and Reichard, S.H. (1992) Current practice in the use of subspecies, variety and forma in the classification of wild plants. Taxon 41: 485-498.

King, M. (1993) Species Evolution: the role of chromosomal change. (Cambridge University Press).

Kovach, W.L. (1993) MVSP - A MultiVariate Statistical Package for IBM PCs ver 2.1. (Kovach Computing Services, Pentraeth, Wales, UK).

Makinson, R.O. (1997) Proteaceae, Grevillen. Flora of Australia 17 ined.

Mayr, E. (1992) A local flora and the biological species concept. Amer. J. Bot. 79: 222-238.

McGillivray, D.J. (1986) New Names in Grevillen (Proteacene) (published by the author: Castle Hill, NSW).

McGillivray, D.J. (1993) Grevillea (Proteacene): A taxonomic revision. (Melbourne University Press: Melbourne).

McLuckie, J. (1930) On Grevillea gaudichaudii R. Br., a supposed natural hybrid between Grevillen laurifolia Sieb. and G. aconthifolia A.C. Part 1 - Analysis of the hybrid. Proc. Linn. Soc. NSW, 55 : 386-416.

Olde, P.M. and Marriott, N.R. (1993a) A taxonomic revision of Grevillea angulata (Proteaceae: Grevilleoideae) and closely related species from the Northern Territory and Western Australia. Telopea 5: 399-417.

Olde, P.M. and Marriott, N.R. (1993b) New species and taxonomic changes in Grevillea (Proteaceae: Grevilleoideae) from south-west Western Australia. Nuytsia 9: 237-304.

Olde, P.M. and Marriott, N.R. (1994a) Grevillea buxifolia (Proteaceae: Grevilleoideae) revisited. Telopea 5: 707-710.

Olde, P.M. and Marriott, N.R. (1994b) A Taxonomic revision of Grevillea arenaria and Grevillea obtusiflora (Proteaceae: Grevilleoideae). Telopea 5: 711-734.

Olde, P.M. and Marriott, N.R. (1994c) Taxonomic studies in Grevillea triternata and Grevillea ramosissima (Proteaceae: Grevilleoideae). Telopea 5: 773-780.

Olde, P.M. and Marriott, N.R. (1995) The Grevillea Book (vols 1-3). (Kangaroo Press: Kenthurst).

Smith, A.B. (1994) Systematics and the fossil record: documenting evolutionary patterns. (Blackwell Scientific Publications).

Sneath, P.H.A. and Sokal, R.R. (1973) Numerical Taxonomy: The Principles and Practice of Numerical Classification. (W.H. Freeman and Co).

Stace, C.A. (1989) Plant Taxonomy and Biosystematics. 2nd ed. (Edward Arnold: London).

Stuessy, T.F. (1990) Plant Taxonomy - The Systematic Evaluation of Comparative Data. (Columbia University Press: New York).

Templeton, A.R. (1989) The Meaning of Species and Speciation: A Genetic Perspective. Pp 3-27 in D. Otte and J. A. Endler (Eds.) Speciation and its Consequences. (Sinauer Associates Inc: Massachusetts).

Tracor Northern Inc. (1987) TN-8500 Image Analysis System. (Middleton: Wisconsin).

West, J.G. and Noble, I.R. (1984) Analysis of digitised leaf images of the Dodonaea viscosa complex in Australia. Taxon 33: 595-613. 


\section{Appendix 1. Character List}

\section{Character}

\section{Floral characters}

1. Floral orientation

2. Pedicel length

3. Pedicel colour

4. Torus width

5. Perianth height

6. Limb length

7. Limb length/Perianth height ratio

8. Perianth length

9. Perianth height/length ratio

10. Nectary height

11. Nectary trichomes

12. Stipe length

13. Ovary length

14. Style length

15. Style width at midpoint

16. Style length/width ratio

17. Pollen-presenter length

18. Pollen-presenter width

19. Pollen-presenter length/width ratio

20. Appendage length (no trichomes)

21. Appendage length (with trichomes)

22. Appendage trichome length

23. Appendage shape

24. Trichome length/Appendage (no trichomes)

\section{Leaf and stem characters}
25. Stem indumentum
26. Petiole indumentum
27. Leaf length
28. Leaf width
29. Aspect ratio
30. Leaf area
31. External leaf perimeter
32. Leaf circularity

33. Leaf rectangularity

34. Leaf abaxial trichome density

\section{Definition}

0 - adaxial, 1 - abaxial.

0 - rusty trichomes sparse/absent, 1 - rusty trichomes present

Sum of the perianth height and limb length

0 -absent, 1 - present.

The distance from the torus to the base of the ovary. The distance from the base to the top of the ovary. The distance from the top of the ovary to the base of the pollen-presenter.

including the rim (if present).

including the rim (if present).

exclusive of trichomes.

inclusive of trichomes

the difference between characters 20 and 21 .

0 - absent, 1 - obtuse, 2 - acute.

The ratio of character 22 : character 20

0 - appressed, 1 - spreading.

0 - appressed, 1 - spreading

maximum leaf projection

The maximum leaf projection perpendicular to the maximum projection

The ratio of leaf length to leaf width

Measured from the number of pixels in a leaf image leaf image perimeter measured from pixel centre to pixel centre

a measure of deviation from a circle (circle value $=1$ ), calculated from the equation: $\quad$ irc $=\underline{\text { (external perimeter })^{2}}$

deviation of leaf shape from a rectangle

(rectangle value $=1$ ),

(West and Noble, 1984)

rectangularity $=\frac{\text { area }}{\text { length } \times \text { width }}$

1 - space between trichomes $>4$ times the width of the trichomes

2 - space between trichomes 2 to 4 times the width of the trichomes

3 - space between trichomes $<2$ times the width of the trichomes

4 - trichomes almost always touching along their whole length

0 - appressed, 1 - spreading 